\title{
空間的キーフレームの制御点軌跡の半自動的生成による アニメーション
}

\author{
Animation by Semi-automatic Generation of Control Point Trajectory \\ in Spatial Key-framing
}

成瀬継太郎（会津大）＼cjkstart関井祥平（会津大）

Keitaro NARUSE, University of Aizu

Shohei SEKII, University of Aizu

\begin{abstract}
Spatial key-framing is one of the methods for generating animation of CG characters, in which a control point corresponding to a full body posture is defined in a workspace, and animation is generated by moving the control point in the workspace. In this paper, we try to develop a CG character animation by generating a trajectory of the control point semi-automatically interacting with a user. We introduce a nonlinear oscillator (van der Pol equation) for the trajectory generation, and evaluate how much it can create a variety of motion and how much it can reflect a user intention, through a computer simulation.
\end{abstract}

Key Words: Animation, Key-framing

\section{1.はじめに}

本論文の目的は，簡単に CG キャラクタのアニメーションを 生成する手法を構築することである.

従来の代表的なアニメーションの生成手法の一つに，モー ションキャプチャを使った方法が挙げられる。これは実際の 人間の動作を取り込み，加工することによってアニメーショ ンを製作するものである．リアルな動作が作れる反面，高価 な設備や処理などが必要となる.

また別の手法として，時間的キーフレーム法が挙げられる. これは,アニメーションの時間軸に沿っていくつかのキーフ レームを設定し，キーフレーム間の画像を対応点閒の補間な どを利用して自動的に生成することにより，アニメーション を生成する手法である，キーフレームや対応点を粗く取ると， 生成されるアニメーションは，動きが不自然なものになって しまう一方，それらを細かくすると自然なアニメーションが 作られうるが，処理が効果になってしまう。

これに対して，空間的キーフレーム法と呼ばれる手法が提 案されている[1]. 空間的キーフレーム法は $C G$ キャラクタの などの動作を生成する手法の一つであり，空間内に定義され る制御点とキャラクタの姿勢を対応させ，制御点を動かすこ とによりキャラクタの動作生成を実現するものである．時間 的キーフレーム法では，キーフレームの設定が重要かつ困難 な課題であったが，空間的キーフレーム法では対話的に制御 点を動かすことにより，キャラクタの動作を直ぐに検証する ことができため，直感的に使い易いものとなっている.

本論文では，空間的キーフレーム法を基本的なアニメーシ ヨン表現手法として導入する。このとき課題となるのが，ど のように，姿勢と制御点を対応付けるか，そしてどのように 制御点を移動させるかということである。本論文では後者の 問題を扱う。制御点の移動は，軌跡だけでなく移動速度も生 成されるアニメーションに影響を与える。そのため, 意図し た動作を実現する制御点の移動軌跡を生成することは，簡単 な問題ではない。そのため，様々な制御点の移動軌跡と対応 するアニメーションを半自動的に生成し，ユーザに提示する ことにより，簡単に意図したアニメーションを生成すること を試みる。多彩な軌道を少ないパラメータで生成する手法と して，非線形振動子，とくに van der Pol 振動子を尊入し, それにより生成される軌道を空間的キーフレーム法の制御点
の移動に適用する。そして，得られたアニメーションの動作 の多彩さや自然さについてケーススタディを行いながら，本 論文の手法を評価する。

\section{2. 空間的キーフレーム法}

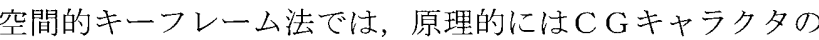
姿勢は各関節角度により定義される。まず準備として，キャ ラクタのある特定の姿勢に対して，その姿勢を代表させる制 御点 (ハンドル) を C Gキャラクタの動作空間中に定義する. そして，生成したい動作を表現するのに十分たくさんの姿勢 と制御点（キー）の組を定義する。次にアニメーションを生 成する際は，動作空間中で自由にハンドルを移動させる。こ のとき，現在のハンドルの位置に最も近いキーを想起し，そ の姿勢を C Gキャラクタにとらせる。一致するキーがない場 合は，そのハンドルに近い複数のキーの姿勢を混合させるこ とにより，任意の地点のハンドルに対応した姿勢を実現する.

このような原理により，ハンドルという一つの点の操作だ けで多数の関節角度のリアルタイムの制御が可能になる.

以上が空間的キーフレーム法の概略であるが，実装する際 には，どの点を制御対象の関節にす心゙きか，各姿勢に対応す るキーをどの位置に設定す心゙きかなどの設計上の問題と，端 点の座標が決まったときに関連する複数の関節角度をどのよ うに決定するのか，また冗長な自由度があるときにどの関節 角度を採用するのかという逆運動学の取り扱いなどを考慮す る必要がある。これらは，最終的に生成されるアニメーショ ンに密接に関連してくる.

Fig. 1 に本論文で扱う C Gキャラクタと空間的キーフレー ム法による動作の一例を示す。図のキャラクタの身体から離 れた点がハンドルであり，四肢の端点が制御の対象となる点 である，実装方法は，キーの位置に対応して四肢の端点を設 定し，その端点の座標から逆運動学を用いて各関節角度を計 算する。

\section{3. van der Pol 振動子}

van der Pol 振動子は非線形の運動方程式であり，次の式で 表現される。 


$$
\frac{d^{2} x}{d t^{2}}-k\left(1-x^{2}\right) \frac{d x}{d t}+x=0
$$

このとき, x と x' の相空間においてリミットサイクルが形 成されることが知られている， $\mathrm{k}=0$ のときは，(1)式は単振動 を表し，初期值に応じた同心円を表す． $0<\mathrm{k}<1$ では，k の值が 大きくなるにつれ歪んだ閉曲線となる。どのような值から出 発しても，最終的には安定した閉軌道（リミットサイクル） に収束することになる. Fig. 2 にリミットサイクルの例を示す.
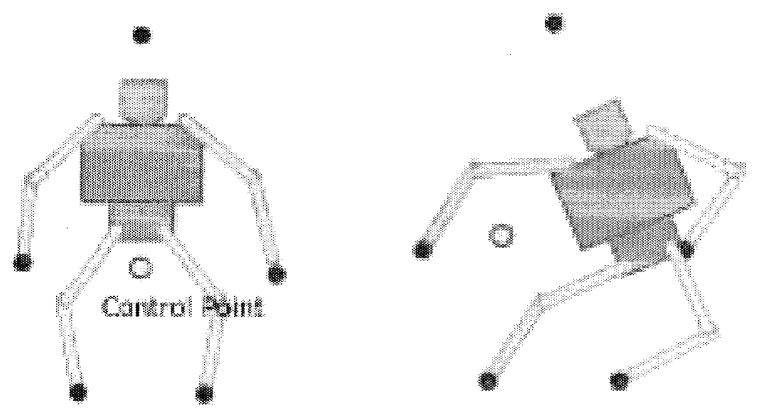

Fig. 1: Instance of Spatial Key-framing

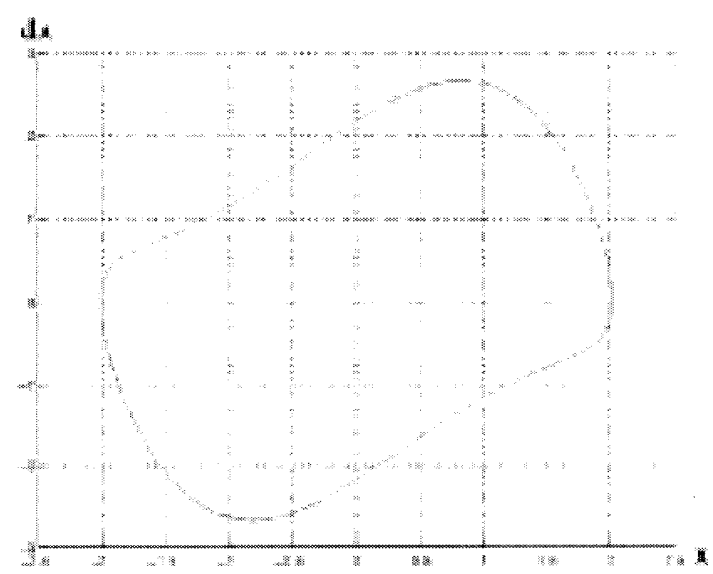

Fig. 2: Example of limit cycle

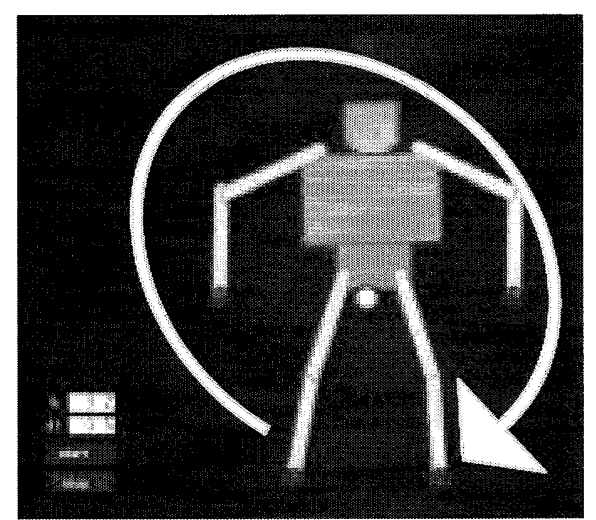

Fig. 3: Semi-automatic generation of trajectory of control point

\section{4. アニメーションの生成}

第 2 節で説明された空間的キーフレームによる C G キャラ クタのハンドルの移動の軌跡に, 前節で述べた van der Pol 振動子のリミットサイクルを適用する。この振動子は k とい
う一つのパラメータで軌跡と移動速度が変化するため, 多彩 な C Gキャラクタの動作が期待される。一方で振動子により 生成されるのは閉曲線であるため, 大きな意味での動きの種 類は変わらない. その代わりに $\mathrm{k}$ の值を変化させた時の, 動 作の「力感」のような印象の異なる動作が実現できるかが期 待される.

そこでケーススタディとして,Fig. 3 に示すような, van der Pol 振動子のパラメータ k とそれを数値計算するときの時間の 刻み幅 $\mathrm{dt}$ を指定して動作を生成し観察する。

Fig. 4 はあるパラメータを与えた時の動作のスナップショ ットである．他の $\mathrm{k}$ の值でも大きな分類では同じような動作 が実現されている，そして，kの值の変化による動作の質感の 違いであるが，本ケーススタディの結果では，顕著な違いは 見られなかった。これは，生成される動作はハンドルの軌跡 に依存寸るが，その中にはどの姿勢をキーとするか，そのキ 一を空閒上のどこに配置するか，そのときに自然に見える動 作にするために逆運動学計算にどのような制約を置くか，な どの他の要素の影響を大きく受けるためである.

そのため, 動きの質感を変更するためには, キネマティク スのようにリンクの長さから決まる值に付け加えた，筋肉の ようなアクチュエータのダイナミクスを考慮する必要がある と考えられる。そしてアクチュエータの力の発生方法に, 非 線形振動子のような力学系を導入すると, 質感の異なる動作 が実現できるかもしれない。この点は今後の課題である。

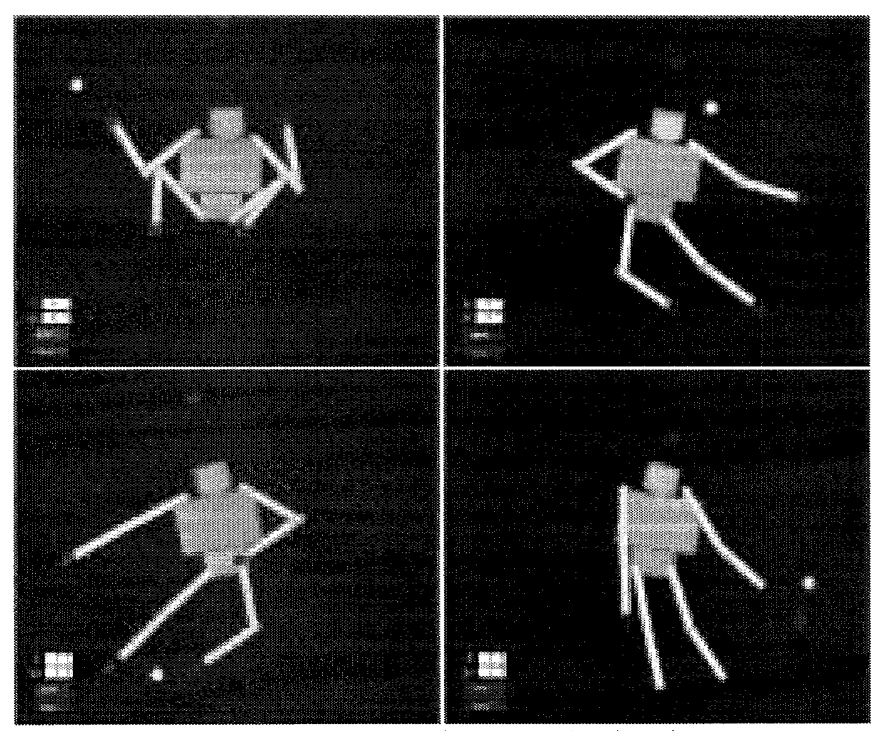

Fig. 4: Snapshot of generated animation

\section{5. おわりに}

本論文では，簡単にアニメーションを生成するために，空 間的キーフレーム法の制御点（ハンドル）の軌跡を，いくつ かのパラメータを与えながら非線形力学系を用いて自動生成 する方法を提案した。そして，その手法を検討するために， 特定にCGキャラクタによりケーススタディを行った.

\section{文 献}

[1] 五十嵐, 「架間的キーフレーム法によるキャラクターアニメーシ ヨン」，インタラクティブシステムとソフトウェアに関するワー クショップ X, (2002) 